\title{
Phytochemical Screening and In Vitro Antioxidant and Anti- inflammatory Activities of Aerial Parts of Euphorbia hirta L.
}

\author{
Deepak Basyal', Astha Neupane ${ }^{1}$, Durga Prasad Pandey ${ }^{2}$, Shiva Pandeya*1 \\ ${ }^{I}$ Department of Pharmacy, Maharajgunj Medical Campus, Institute of Medicine, Tribhuvan University, \\ Kathmandu, Nepal \\ ${ }^{2}$ Research Center for Applied Science and Technology (RECAST), Tribhuvan University, Kirtipur, Kathmandu, Nepal \\ *Corresponding E-mail: shivapandeya@iom.edu.np
}

(Received: September 27, 2020; Revised: January 4, 2021; \& Accepted: January 18, 2021)

\begin{abstract}
Euphorbia hirta L (Euphorbiaceae) also called asthma herb has long been prescribed in traditional medicine because it exhibits diverse pharmacological actions due to the presence of alkaloids, flavonoids, polyphenols, triterpenoids, and saponins. The present study is aimed at the study of phytochemical and antioxidant activity and anti-inflammatory screening of E. hirta. Extraction of dried powder was performed followed by phytochemical screening using color reactions. Total phenolic content (TPC) and total flavonoid content (TFC) of the extracts were estimated by Folin-Ciocalteu and Aluminum chloride method respectively. The antioxidant activity was studied by the 2,2-diphenyl-1-picrylhydrazyl (DPPH) free radical scavenging method. Anti-inflammatory activity was studied by using protein denaturation in vitro bioassay. Phytochemical screening showed the presence of flavonoids, alkaloids, and phenolic compounds. TPC, TFC and antioxidant activity $\left(\mathrm{IC}_{50}\right)$ of the extract were found as $288.10 \mathrm{mg}$ gallic acid equivalent per gram (GAE/g), $29.36 \mathrm{mg}$ quercetin equivalent per gram $(\mathrm{QE} / \mathrm{g})$ and $32.23 \mu \mathrm{g} / \mathrm{mL}(\mathrm{p}<0.05)$ respectively. Diclofenac sodium and E. hirta extract showed the maximum inhibition of $91.28 \%$ and $68.20 \%$ respectively at the concentration of $1000 \mu \mathrm{g} / \mathrm{mL}$ compared with control ( $\mathrm{p}>0.05)$. The phenolic compounds and flavonoids exert antioxidant and anti-inflammatory activities because of their scavenging ability. The demonstrated antioxidant and anti-inflammatory activities may be the rationale behind some of its folkloric uses and also may be responsible for some of its pharmacological effects. Thus, E. hirta can be considered a good source of antioxidants and anti-inflammatory actions, which might be beneficial for combating oxidative stress.
\end{abstract}

Keywords: Euphorbia hirta L, DPPH, Folin-Ciocalteu, aluminum chloride, protein denaturation

\section{Introduction}

Throughout the development of human culture using natural products has had magical-religious significance- often been the only means to treat physical injuries and other diseases [1]. During the last few decades in drug discovery and drug development, a secondary role was played by natural products [2]. Therefore, there has been an increasing interest in the study of medicinal plants and their traditional use in different parts of the world. Plants represent a largely untapped source of structurally novel compounds that might serve as a lead for the development of novel drugs [3]. This has successfully led to many kinds of research and hypothesis supporting findings. The complex chemical metabolites present in the plant harbor an inexhaustible source of active ingredients invaluable in the management of many intractable diseases $[4,5]$.
Oxidative stress is an imbalance in the redox status of a cell and the excessive production of free radicals, which are the most reactive molecules in the biological system [6]. Free radicals are constantly generated and can cause extensive damage to tissues and biomolecules, causing various chronic and degenerative diseases, such as coronary heart disease, inflammation, stroke, diabetes mellitus, and cancer [7,8]. Antioxidant activity usually means the ability of a compound to delay, inhibit, or prevent the oxidation of oxidizable materials by scavenging free radicals and reducing oxidative stress [9]. Antioxidation is an extremely significant activity, which can be used as a preventive agent against several diseases [10]. Due to the adverse side effects of synthetic drugs, natural antioxidants of plant origin have drawn much attention in recent years [11]. Plants are known to possess potent 
bioactive compounds capable of preventing and treating most oxidative-related diseases and these compounds might act as leads in drug development [12].

Inflammation is a complex biological adaptive response or process triggered by noxious stimuli and conditions such as infection and tissue injury [13]. Inflammatory diseases are a major cause of morbidity and mortality in the world [14]. It has extensively been demonstrated that strong and complex interconnections occur between oxidative stress and the inflammatory response. At the site of inflammation, overproduction of reactive oxygen species (ROS) predominates subsequent oxidative stress and potentially cause damage to biomolecules such as DNA, lipids, and proteins [15]. A plethora of evidence for herbal medications garnered wide interest as complementary and alternative therapeutics. Nowadays, search for natural entities with anti-inflammatory activity with lesser side effects is vital. Therefore, efforts are being continuously made to identify such agents and to validate their scientific authenticity.

Euphorbia hirta (Euphorbiaceae) native to India, also known as Dhudejhar in Nepal, is mostly found in the moist place at elevation up to 1,800 meters. There are approximately 1600 species in the Euphorbia genus, and many of these are grown throughout Asia because of their pharmacological properties. It is an annual herb that grows erect up to $20 \mathrm{~cm}$ to $60 \mathrm{~cm}$ high with a hairy solid stem that produces white latex $[16,17]$. The leaves and stems of $E$. hirta produce a milky-white juice when cut [18]. It is frequently seen growing open waste spaces, banks of watercourses, pathways, roadsides, and grasslands [19]. Different classes of phytochemicals like flavonoids, polyphenols, tannins, triterpenes, phytosterols, and alkaloids are reported in this plant [20]. The plant has sedative, anxiolytic, analgesic, antipyretic, anti-inflammatory, and diuretic properties [21]. Furthermore, studies revealed that the plant possesses galactogenic, anti-microbial, antioxidant, antidiarrhoeic, antihypertensive anticancer, antimalarial, repellent, and antifeedant activities [22]. Previous studies have attempted to characterize the chemical compounds present in $E$. hirta but there is a lack of information relating to the specific constituents of E. hirta and their potential clinical applications [23]. Moreover, herbs are a more efficacious, safe, economic, and reliable, less toxic, and accessible natural resource of drugs all over the world. So, the present study aims to assess the qualitative and quantitative phytochemical screening and investigate the in vitro antioxidant activity of $E$. hirta, and evaluate its potential for clinical use as a natural antioxidant and anti-inflammatory agent.

\section{Materials and Methods}

\section{Plant collection and extraction}

The fresh aerial part of the plant was collected from the open grassland of Gaidakot, Nawalparasi, Nepal. It was identified in National Herbarium and Plant Tissue Culture Laboratory, Lalitpur, Nepal. It was cut into pieces and shade dried for 20 days. The dried sample was pulverized to powder using a mechanical grinder. It was passed through sieve number 60 for uniformity. The extraction, phytochemical screening, and antioxidant activity evaluation were carried out at Chemistry, Pharmacognosy and Pharmacology laboratory of Department of Pharmacy, Maharajgunj Medical Campus, Institute of Medicine, Kathmandu, and National Academy of Science and Technology, Khumaltar, Lalitpur, Nepal.

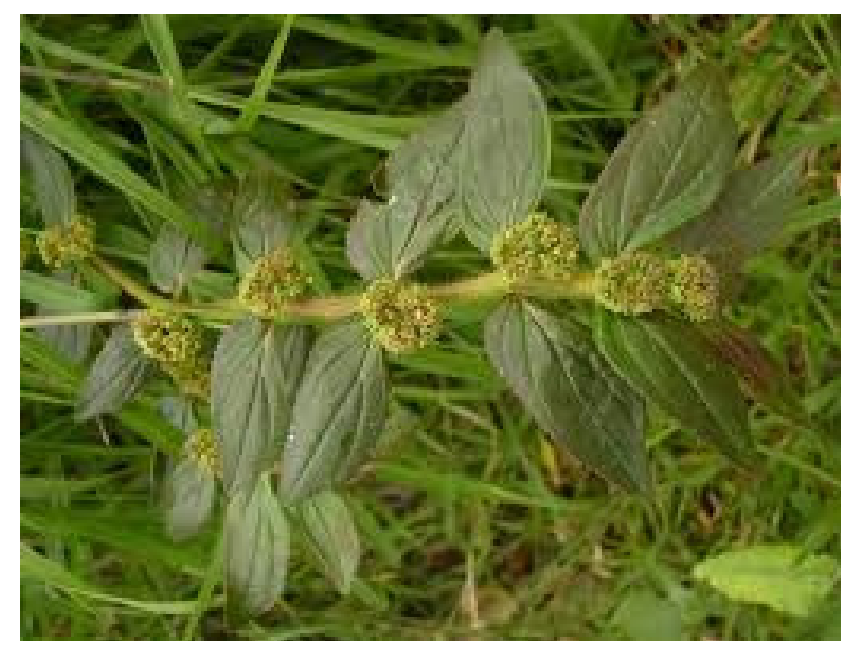

Figure 1: Aerial plant part with leaves of Euphorbia hirta $L$

$200 \mathrm{~g}$ powder was first extracted with $600 \mathrm{~mL}$ methanol by maceration for 24 hours. The methanol extract was obtained by filtration through a vacuum filter. The extract was further concentrated to $150 \mathrm{~mL}$ in a rotary vacuum evaporator. $100 \mathrm{~mL}$ water was added to the concentrated methanol extract and then extracted with $200 \mathrm{~mL}$ ethyl acetate in a separating funnel three times. The ethyl acetate layer was concentrated to $1 / 4^{\text {th }}$ in rotary vacuum evaporator at $40^{\circ} \mathrm{C}, 20 \mathrm{~mL}$ of $10 \% \mathrm{H}_{2} \mathrm{SO}_{4}$ was added and allowed to stand overnight. The solution was again extracted with ethyl acetate in a separating funnel. The ethyl acetate layer was taken evaporated to dryness using a rotary vacuum evaporator. The dried crude extract was then stored in the fridge until ready for use. All 
chemicals were of analytical reagent grade and were used without further purification.

\section{Qualitative phytochemical screening}

The phytochemical screenings of different classes of secondary metabolites were performed according to standard test protocol [24].

\section{Quantitative phytochemical screening}

Total phenolic contents (TPC)

Total phenolic content was determined by FolinCiocalteu (FC) method with slight modification [25-26]. Same volume $(0.5 \mathrm{~mL})$ of the plant extract $(1 \mathrm{mg} / \mathrm{mL})$ and different concentrations of gallic acid as standard $(10-120 \mu \mathrm{g} / \mathrm{mL})$ were taken and 0.1 $\mathrm{mL}$ 1:2 FC reagent was added along with $0.8 \mathrm{~mL}$ deionized water. After 3 minutes of incubation, 0.3 $\mathrm{mL}$ of $\mathrm{Na}_{2} \mathrm{CO}_{3}$ was added and allowed to stand for 30 minutes at room temperature. After 30 minutes absorbance was taken at $765 \mathrm{~nm}$ against the methanol as blank in 96 wells plate ELISA reader. The total phenolic content of all the samples was calculated as the mg GAE/gram of dry extract with the help of the equation obtained from the standard curve. All the tests were done in triplicates.

The amount of phenol in plant extracts was calculated by the following formula.

$$
\mathrm{T}=\mathrm{C} \times \mathrm{V} / \mathrm{M}
$$

where, $\mathrm{T}=$ Total Phenolic content $\mathrm{mg} / \mathrm{g}, \mathrm{C}=$ The concentration of Gallic acid established from the calibration curve $(\mathrm{mg} / \mathrm{mL}), \mathrm{V}=$ The volume of extract solution $(\mathrm{mL}), \mathrm{M}=$ The weight of the plant extract $(\mathrm{g})$

\section{Preparation of standard solution}

The gallic acid and quercetin 10mg were accurately weighed into a $10 \mathrm{~mL}$ volumetric flask, dissolved in $10 \mathrm{~mL}$ methanol and the solution was made up to $10 \mathrm{~mL}$ with the same solvent $[1 \mathrm{mg} / \mathrm{mL}]$. Several dilutions of the standard solution were performed and the respective absorbance was determined.

\section{Total flavonoid content (TFC)}

Total flavonoid content was estimated by the aluminum chloride method with slight modification [25-26]. Equal volume $(1.5 \mathrm{~mL})$ of the plant extract $(1 \mathrm{mg} / \mathrm{mL})$ and standards of different concentrations (10-60 mg/mL) were mixed with $75 \mu \mathrm{L} 5 \% \mathrm{NaNO}_{2}$ and incubated for 6 minutes. After that $150 \mu \mathrm{L}$ of $10 \%$, $\mathrm{AlCl}_{3}$ was added to the mixture and again incubated for 6 minutes. After 6 minutes, $0.5 \mathrm{~mL}$ of $1 \mathrm{M} \mathrm{NaOH}$ was added and the total volume was made up to 3 $\mathrm{mL}$ with deionized water. The reaction mixture was shaken and the absorbance was measured at 510 $\mathrm{nm}$ in 96 wells plate ELISA reader. Total flavonoid content was expressed as the mg equivalents of quercetin per gram of dry extracts with the help of an equation obtained from the standard and all the tests were performed in triplicates.

The total content of flavonoid in plant extracts was calculated by the following formula:

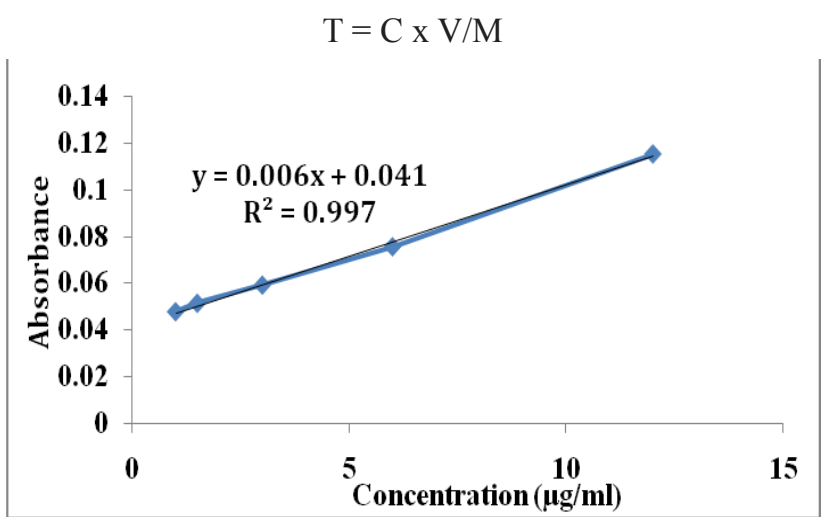

Figure 2: Calibration curve of gallic acid

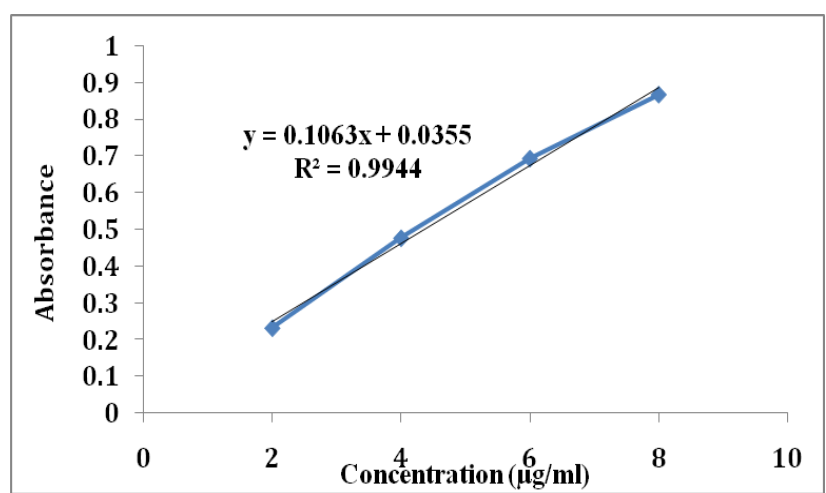

Figure 3: Calibration curve of quercetin

where, $\mathrm{T}=$ Total flavonoid content $(\mathrm{mg} / \mathrm{g}), \mathrm{C}=\mathrm{The}$ concentration of Quercetin established from the calibration curve $(\mathrm{mg} / \mathrm{mL}), \mathrm{V}=$ The volume of extract solution ( $\mathrm{mL}), \mathrm{M}=$ The weight of the plant extract $(\mathrm{g})$

\section{Antioxidant assay (DPPH free radical scavenging assay)}

2,2-diphenyl-1-picrylhydrazyl (DPPH) was used to determine the free radical scavenging activity of extracts [26]. DPPH assay is routinely employed in laboratories for determining the free radical scavenging potential of purified phenolic compounds and natural plant extracts since the assay is rapid, easy, and inexpensive. The principle of this assay is based on the reduction of DPPH, a free stable radical by an antioxidant according to the following reaction. During the reaction, the alcoholic solution of DPPH 


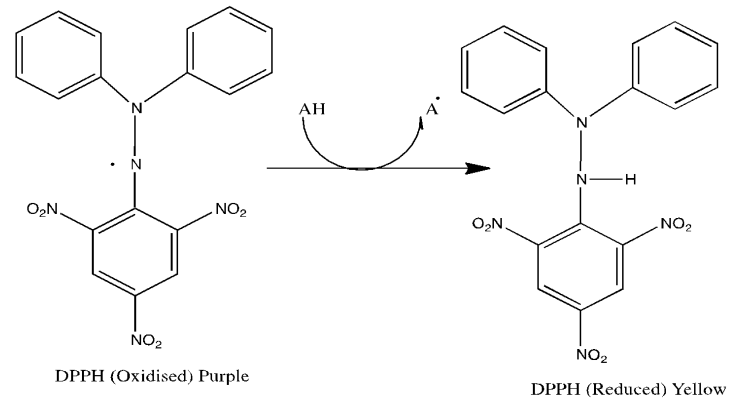

turns from deep violet or purple color to light yellow color. For the DPPH assay, $2.5 \mathrm{~mL}$ of different concentrations $(3-100 \mu \mathrm{g} / \mathrm{mL})$ of plant extracts, as well as standard (ascorbic acid), was made in test tubes. Then $1 \mathrm{~mL}$ of $0.3 \mathrm{mM}$ freshly prepared DPPH was added to the samples mixed well and incubated in dark for 30 minutes. After incubation absorbance was taken at the wavelength of $517 \mathrm{~nm}$ in 96 wells plate ELISA reader and all the tests were done in triplicates. Lower the absorbance of the reaction mixture indicates higher free radical scavenging activity. The percentage scavenging of DPPH by the extracts was calculated according to the following formula.

$$
\left.\% \text { Inhibition }=\left(\mathrm{A}_{\text {control }}-\mathrm{A}_{\text {sample }}\right) / \mathrm{A}_{\text {control }}\right) \times 100
$$

To assess the antioxidant potency, the $\mathrm{IC}_{50}$ (defined as the concentration of substrate that causes $50 \%$ reduction of the DPPH color) was calculated graphically using a calibration curve in the linear range by plotting the extract concentration versus the corresponding scavenging effect. The lower the $\mathrm{IC}_{50}$ value, the higher is the antioxidant activity.

\section{In-vitro Anti-inflammatory action (Inhibition of albumin denaturation)}

The anti-inflammatory activity of $E$. hirta was studied by using the inhibition of the albumin denaturation technique [27-28]. A volume of $1 \mathrm{~mL}$ of extracts (aqueous and ethanolic) or of diclofenac sodium at different concentrations $(100,200,500$, and $1000 \mu \mathrm{g} /$ $\mathrm{mL}$ ) was homogenized with $1 \mathrm{~mL}$ of an aqueous solution of bovine serum albumin $(5 \%)$ and incubated at $27^{\circ} \mathrm{C}$ for 15 minutes. The mixture of distilled water and BSA constituted the control tube. Denaturation of the proteins was caused by placing the mixture in a water bath for 10 minutes at $70^{\circ} \mathrm{C}$. The mixture was cooled inside the ambient room temperature, and the activity of each mixture was measured at $660 \mathrm{~nm}$ (SHIMADZU, UV 1800). Each test was done three times. The following formula was used to calculate inhibition percentage.
$\%$ inhibition $=($ Absorbance Control - Absorbance
Sample $) /($ Absorbance Control $) \times 100$

The increments in absorbance of the test sample concerning control indicated stabilization of protein i.e., inhibition of protein (albumin) denaturation or anti-denaturation effect by the test extract and the reference drug Diclofenac sodium.

\section{Statistical analysis}

The results were presented as Mean $\pm \mathrm{SD}$. Statistical analyzes of data were performed using one-way analysis of variance (ANOVA) followed by Post Hoc Tukey test using SPSS ver. 25 Significant differences were considered at $p<0.05$.

\section{Results and Discussion \\ Qualitative phytochemical screening}

Phytochemical screening of the ethyl acetate extract showed the presence of flavonoids, alkaloids, and phenolic com pounds.

Table 1: Phytochemical screening of ethyl acetated extract

\begin{tabular}{|c|c|c|}
\hline \multicolumn{3}{|c|}{ of E. hirta } \\
\hline $\begin{array}{l}\text { Secondary } \\
\text { metabolites }\end{array}$ & Chemical test & $\begin{array}{l}\text { Ethyl } \\
\text { acetate } \\
\text { extract }\end{array}$ \\
\hline \multirow[t]{3}{*}{ Flavonoids } & Shinoda test & ++ \\
\hline & Alkaline reagent test & ++ \\
\hline & Lead acetate test & ++ \\
\hline \multirow[t]{4}{*}{ Alkaloids } & Mayer's test & - \\
\hline & Wagner's test & + \\
\hline & Hager's test & - \\
\hline & Dragendorff reagent & + \\
\hline Phytosterols & $\begin{array}{l}\text { Libermann } \\
\text { Burchard's test }\end{array}$ & - \\
\hline Carbohydrates & Molisch's Test & - \\
\hline Proteins & Ninhydrin Test & - \\
\hline \multirow[t]{2}{*}{ Saponins } & Hemolysis test & - \\
\hline & Froth test & - \\
\hline $\begin{array}{l}\text { Phenolic } \\
\text { compounds }\end{array}$ & Ferric chloride test & + \\
\hline
\end{tabular}

\section{Total phenolic content}

The total phenol contents of plant extracts were calculated from the regression equation of the 
calibration curve. The total phenolic content in ethyl acetate extracts was found to be $288.10 \mathrm{mg} \mathrm{GAE} / \mathrm{g}$.

\section{Total flavonoid content}

The total flavonoid contents of plant extracts were calculated from the regression equation of the calibration curve. The total flavonoid content of ethyl acetate extract was found to be $29.36 \mathrm{mg} \mathrm{QE} / \mathrm{g}$.

\section{Anti-oxidant activity}

The antioxidant activity $\left(\mathrm{IC}_{50}\right)$ of the ethyl acetate extract was carried out by using DPPH free radical scavenging assay and it was found to be $32.23 \mu \mathrm{g} / \mathrm{mL}$.

Table 2: In-vitro anti-inflammatory action of Diclofenac sodium versus E. hirta extract

\begin{tabular}{|c|c|c|c|}
\hline $\begin{array}{l}\text { Dose } \\
(\mu \mathrm{g} / \mathrm{mL}) \\
\text { Diclofenac }\end{array}$ & $\begin{array}{l}\text { Protein } \\
\text { denaturation } \\
\text { (\% Inhibition) }\end{array}$ & $\begin{array}{l}\text { Dose } \\
(\mu \mathrm{g} / \mathrm{mL}) \\
\text { extract }\end{array}$ & $\begin{array}{l}\text { Protein } \\
\text { denaturation } \\
\text { (\% Inhibition) }\end{array}$ \\
\hline 100 & 73.32 & 100 & 46.23 \\
\hline 200 & 78.61 & 200 & 52.12 \\
\hline 500 & 82.16 & 500 & 59.24 \\
\hline 1000 & 91.28 & 1000 & 68.20 \\
\hline
\end{tabular}

\section{In-vitro anti-inflammatory action}

The present results exhibited a concentrationdependent inhibition of protein (albumin) denaturation by the extracts. The percentage values were obtained using various concentrations of test compounds, and readings are presented as the mean of triplicates. A standard anti-inflammation drug, Diclofenac sodium showed the maximum inhibition of $91.28 \%$ at the concentration of $1000 \mu \mathrm{g} / \mathrm{mL}$ compared with control (Table 2) whereas in the case of extract maximum inhibition of 68.20 was observed at a concentration of $1000 \mu \mathrm{g} / \mathrm{mL}$ compared with control. There was no significant difference in the anti-inflammatory activity of standard drug diclofenac sodium and extract $(p>0.05)$ so the anti-inflammatory activity of the extract was comparable with standard diclofenac sodium extract and reference drug. Further definitive studies are necessary to ascertain the mechanisms and constituents behind its anti-inflammatory actions both in vivo and in vitro.

Medicinal plants are since ancient times lauded for their diverse pharmacological actions which could be attributed to the presence of secondary metabolites such as alkaloids, flavonoids, glycosides, tannins, steroids, etc.[29-30]. Some of these plants are important sources of natural antioxidants that have been shown to reduce the risk and progression of certain acute and chronic diseases such as cancer, heart diseases, and stroke by scavenging free radicals which are impetrated in the pathogens us of many diseases [31].

Many studies suggest that polyphenols and flavonoids exert antioxidant and anti-inflammatory activities by scavenging hydroxyl radicals, superoxide anions, and lipid peroxy radicals [31-32]. In our study total phenol content and total flavonoid content was calculated as $288.10 \mathrm{mgGAE} / \mathrm{g}$ and $29.36 \mathrm{mg}$ QE/g respectively. In a study conducted by Basma et al. [32] total phenolic content of E. hirta leaves, flower, root, and stem extract was calculated as $206.17 \mathrm{mgGAE} / \mathrm{g}, 117.08$ $\mathrm{mgGAE} / \mathrm{g}, 83.15 \mathrm{mgGAE} / \mathrm{g}$, and $65.70 \mathrm{mgGAE} / \mathrm{g}$, respectively. On the other hand, total flavonoid content in leaves, flowers, roots and stems extracts was calculated as $(37.970 \pm 0.003) \mathrm{mgQE} / \mathrm{g}, 35.20$ $\mathrm{mgQE} / \mathrm{g}, 24.350 \mathrm{mgQE} / \mathrm{g}$, and $24.120 \mathrm{mgQE} / \mathrm{g}$, respectively. A similar study conducted by Asha $\mathrm{S}$ et al [33] determined total phenol content as 275.64 $\mathrm{mgGAE} / \mathrm{g}, 291.74 \mathrm{mgGAE} / \mathrm{g}$, and $285.41 \mathrm{mgGAE} / \mathrm{g}$ in aqueous, ethanolic, and methanolic extract respectively, and total flavonoid content as $26.37 \mathrm{mg}$ $\mathrm{QE} / \mathrm{g}, 40.32 \mathrm{mg} \mathrm{QE} / \mathrm{g}$, and $32.29 \mathrm{mgQE} / \mathrm{g}$ in aqueous, ethanolic and methanolic extract respectively.

Plant polyphenols produced either from phenylalanine or its precursor Shikimic acid, are important dietary antioxidants because they possess ideal structural chemistry for free radical scavenging activity [34]. Numerous in vitro studies have shown antioxidant potential in protecting against many diseases [35]. Plants have diverse groups of polyphenolic compounds, such as simple phenolic, phenolic acids, anthocyanins, hydroxycinnamic acid derivatives, and flavonoids [36,37]. All these phenolic classes have gained extensive attention because of their physiological functions, including free radical scavenging, anti-mutagenic, anticarcinogenic, and anti-inflammatory effects $[37,38]$. The antioxidant activity of phenolics is largely due to their redox properties which make them act as reducing agents, hydrogen donors, singlet oxygen quenchers, and as well as potential metal chelators [39].

Polyphenol is the major plant compound with a high level of antioxidant activity [40]. This activity is due to their ability to absorb, neutralize, and quench free radicals [41]. Their ability as free radical scavengers could also be attributed to their redox properties, presence of conjugated ring structures, and carboxylic group, which have been reported to inhibit lipid peroxidation [42]. The phenolic compounds and 
flavonoids were found to play an important role in antioxidative activity because of their scavenging ability due to their hydroxyl groups [43]. There are certain problems associated with the use of animals in experimental pharmacological research such as ethical issues and the lack of rationale for their use when other suitable methods are available or could be investigated [44]. Hence, in the present study, the protein denaturation bioassay was selected for in vitro assessment of the anti-inflammatory property. Denaturation of the tissue proteins is one of the well-documented cases of inflammatory and arthritic diseases [45]. Production of auto-antigens in certain arthritic diseases may be due to the denaturation of proteins in vivo [46]. Therefore, using agents that can prevent protein denaturation would be worthwhile for anti-inflammatory drug development.

The DPPH test provides information on the reactivity of the test compounds with a stable free radical, though DPPH radical is absent in biological systems [47]. The DPPH assay is often used to evaluate the ability of antioxidants to scavenge the free radicals from test samples. Whereby, the free radicals cause biological damage through oxidative stress and such process lead to many disorders like neurodegenerative diseases, cancer, and AIDS [48]. Therefore, DPPH assay is an effective method to measure their scavenging power. However, the degree of reduction in absorbance is an indication of the radical scavenging (antioxidant) power of an agent [49], it was observed that the free radical scavenging activity of extract increased with increasing concentration. The antioxidant principle in their interaction depends on oxidative free radicals. The main mechanism of the DPPH method is that the bioactive compounds react with the stable free radical i.e., 1,1-diphenyl- $\beta$-picrylhydrazyl. It is converted to 1,1-diphenyl- $\beta$-picrylhydrazine with color change. The color changes can be measured quantitatively by spectrophotometer absorbance at $517 \mathrm{~nm}$. The gradually color change indicates the scavenging activities of the plant crude sample due to bioactive compounds such as phenolic compounds, flavonoids, terpenoids, and derivatives [50-52].

Inflammation is a symptom of many chronic diseases. It is a normal protective response to tissue injury caused by physical trauma, noxious chemical, or by microbial agents [53]. Inflammation is a protective attempt by the body to remove injurious stimuli as well as initiate the healing process of the tissue [54]. Medicinal plants used in traditional medicine to treat anti-inflammatory conditions seem viable and logical alternatives in search of safe and effective anti-inflammatory agents [55]. Hence, in this study plant extract was subjected to a simple and viable protein denaturation bioassay method to evaluate its potential as an anti-inflammatory drug. It is wellknown fact that denaturation of tissue protein leads to inflammatory and arthritic diseases.

Protein denaturation is a process in which proteins lose their tertiary structure and secondary structure by application of external stress or compound, such as strong acid or base, a concentrated inorganic salt, an organic solvent, or heat [56]. Most biological proteins lose their biological function when denatured. Denaturation of proteins is a well-documented cause of inflammation [57]. As part of the investigation on the mechanism of the anti-inflammation activity, the ability of plant extract to inhibit protein denaturation was studied. It was effective in inhibiting heatinduced albumin denaturation. Extract effect on inhibition of protein denaturation was found to be comparable with the standard drug diclofenac sodium. Our results correlate the reduction of free radical production with the anti-inflammatory effect of this plant. The results of the present work suggest that the anti-inflammatory activities of the same extracts could be explained, at least in part, by their antioxidant properties [58]. The results indicated that this plant is worthy of further investigation as an antiinflammatory drug. It contains an anti-inflammatory principle that may be useful in the treatment of acute inflammatory conditions. Although not fully understood, several action mechanisms are proposed to explain in vivo anti-inflammatory action. One of the important mechanisms is inhibition of eicosanoid generating enzymes including phospholipase $A_{2}$, cyclooxygenases, and lipoxygenases, thereby reducing the concentrations of prostanoids and leukotrienes [59]. Recent studies have also shown that certain flavonoids, especially flavone derivatives, express their anti-inflammatory activity at least in part by modulation of pro-inflammatory gene expressions such as cyclooxygenase-2, inducible nitric oxide synthase, and several pivotal cytokines. Due to these unique action mechanisms and significant in vivo activity, flavonoids are considered to be reasonable candidates for new anti-inflammatory drugs [60]. Further, the study shall be aimed at isolating and identifying the substances responsible for the anti-oxidant and anti-inflammatory activities of 
plant extracts which may be further exploits in the formulation of the medicine. Furthermore, in vivo antioxidant and anti-inflammatory activities of these extracts need to be assessed. It is necessary to investigate further and understand the relationship between anti-oxidant and anti-inflammatory activities of flavonoid and phenolic compounds in the plant extract under study. It may, therefore, be concluded from this study that understanding the reaction mechanisms can help in evaluating the antioxidant and anti-inflammatory activities of various compounds as well as in the development of the novel drug.

\section{Conclusion}

This study enhances the ability of E. hirta extract as an excellent natural source for antiradical scavenging. Thus, it can be considered as a good source of antioxidants which might be beneficial for combating oxidative stress. Therefore, the results may be taken into account for the development of herbal medicine to treat diseases related to oxidative damage. Further study is necessary for isolation and characterization of the active antioxidant and anti-inflammatory agents, which can be used to treat various oxidative stressrelated diseases. Furthermore, in vivo antioxidant and anti-inflammatory activities of these extracts need to be assessed.

\section{Acknowledgments}

The authors are thankful to the National Academy of Science and Technology, Khumaltar, Lalitpur for their technical support and Department of Pharmacy, Maharajgunj Medical Campus, Institute of Medicine, Tribhuvan University for providing the facilities for carrying out this research work.

\section{References}

1. R. R. N. Alves, and H. N. Alves, The faunal drugstore: Animal-based remedies used in traditional medicines in Latin America, Journal of Ethnobiology and Ethnomedicine, 2011, 7(9),143. (DOI: 10.1186/1746-4269-7-9)

2. F. E. Koehn, and G. T. Carter, The evolving role of natural products in drug discovery, Nature Reviews Drug Discovery, 2005, 4(3), 206-220. (DOI: 10.1038/nrd1657)

3. P. Scartezzini andE. Speroni, Review on someplants of Indian traditional medicine with antioxidant activity, Journal of Ethnopharmacology, 2000, 71(1-2), 23-43. (DOI: 10.1016/S03788741(00)00213-0).
4. P. Ljubuncic, I. Portnaya, U. Cogan, H. Azaizeh and A. Bomzon, Antioxidant activity of Crataegus aronia aqueous extract used in traditional Arab medicine in Israel, Journal of Ethnopharmacology, 2005, 101(1-3), 153-161. (DOI: 10.1016/j.jep.2005.04.024).

5. S. E. Lee, H. J. Hwang, J. S. Ha, H. S. Jeong, and J. H. Kim, Screening of medicinal plant extracts for antioxidant activity, Life Sciences, 2003, 73(2), 167-179. (DOI: 10.1016/S0024-3205(03)00259$5)$.

6. H. Zhang, R Tsao, Dietary polyphenols, oxidative stress, and antioxidant and anti-inflammatory effects. Current Opinion in Food Science, 2016, 8, 33-42. (DOI: 10.1016/j.cofs.2016.02.002).

7. G. Miliauskas, P. R. Venskutonis and T. A. Van Beek, Screening of radical scavenging activity of some medicinal and aromatic plant extracts, Food Chemistry, 2004, 85(2), 231-237. (DOI: 10.1016/j. foodchem.2003.05.007).

8. H. B. Li, C. C. Wong, K. W. Cheng and F. Chen, Antioxidant properties in vitro and total phenolic contents in methanol extract from medicinal plants, LWT-Food Science and Technology, 2008, 41(3), 385-390. (DOI: 10.1016/j. lwt.2007.03.011).

9. H. Guo, K. Saravanakumar and M. H. Wang, Total phenolic, flavonoid contents and free radical scavenging capacity of extracts from tubers of Stachys affinis, Biocatalysis, and Agricultural Biotechnology, 2018 1(15), 235-239. (DOI: 10.1016/j.bcab.2018.06.009).

10. Y. Zou, Y. Lu and D. Wei, Antioxidant activity of a flavonoid-rich extract of Hypericum perforatum L. in vitro, Journal of Agricultural and Food Chemistry, 2004, 52(16), 5032-5039. (DOI: 10.1021/jf049571r).

11. F. Shahidi and Y. Zhong, Novel antioxidants in food quality preservation and health promotion. European Journal of Lipid Science and Technology, 2010, 112(9), 930-40. (DOI: 10.1002/ ej1t.201000044).

12. A. Banerjee, N. Dasgupta and B. De, In vitro study of antioxidant activity of Syzygium cumini fruit, Food Chemistry, 2005, 90(4), 727-733. (DOI: 10.1016/j.foodchem.2004.04.033).

13. L. Chen, H. Deng, H. Cui, J. Fang J, Z. Zuo, J. Deng, Y. Li, X. Wang and L. Zhao, Inflammatory responses and inflammation-associated diseases in organs, Oncotarget, 2018, 9(6), 7204. (DOI: 
10.18632/oncotarget.23208).

14.M. J. Sevenoaks, and R. A. Stockley, Chronic obstructive pulmonary disease, inflammation and co-morbidity-a common inflammatory phenotype, Respiratory Research, 2006, 7(1), 70. (DOI: 10.1186/1465-9921-7-70)

15.P. S Whitton, Inflammation as a causative factor in the etiology of Parkinson's disease, British Journal of Pharmacology, 2007, 150(8), 963-976. (DOI: 10.1038/sj.bjp.0707167).

16.A. A.Basma, Z. Zakaria, L.Y. Latha and S. Sasidharan, Antioxidant activity and phytochemical screening of the methanol extracts of Euphorbia hirta L, Asian Pacific Journal of Tropical Medicine, 2011, 4(5), 386-390. (DOI: 10.1016/S1995-7645(11)60109-0).

17.R. Naz and A. Bano, Phytochemical screening, antioxidants and antimicrobial potential of Lantana camara in different solvents, Asian Pacific Journal of Tropical Disease, 2013, 3(6). 480-486. (DOI: 10.1016/S2222-1808(13)60104-8).

18. M. Valko, D. Leibfritz, J. Moncol, M. T. Cronin, M. Mazur and J. Telser, Free radicals and antioxidants in normal physiological functions and human disease, The International Journal of Biochemistry \& Cell Biology, 2007, 39(1):44-84. (DOI: 10.1016/j.biocel.2006.07.001).

19. S. M. Rahman, S. Rana, M. N. Islam, A. Kumer, M. M. Hassan, T. K. Biswas and M. Atikullah, Evaluation of anxiolytic and sedative-like activities of methanolic extract of Euphorbia hirta leaves in mice, Pharmacology \& Pharmacy, 2019, 10(6), 283-297. (DOI:10.4236/pp.2019.106023).

20. N. Sharma, K. W. Samarakoon, R. Gyawali, Y. H. Park, S. J. Lee, S. J. Oh, T. H. Le and D. K. Jeong, Evaluation of the antioxidant, anti-inflammatory, and anticancer activities of Euphorbia hirta ethanolic extract, Molecules, 2014, 19(9).1456714581. (DOI: 10.3390/molecules190914567).

21.S. Kumar, R. Malhotra and D. Kumar, Euphorbia hirta: Its chemistry, traditional and medicinal uses, and pharmacological activities, Pharmacognosy Reviews, 2010, 4(7), 58. (DOI: 10.4103/09737847.65327).

22. S. Kumar, R. Malhotra and D. Kumar, Antidiabetic and free radicals scavenging potential of Euphorbia hirta flower extract, Indian Journal of Pharmaceutical Sciences, 2010, 72(4), 533. (DOI: 10.4103/0250-474X.73921).

23.M. A. Rajeh, Z. Zuraini, S. Sasidharan, L. Y.
Latha, S. Amutha, Assessment of Euphorbia hirta L. leaf, flower, stem and root extracts for their antibacterial and antifungal activity and brine shrimp lethality, Molecules, 2010, 15(9), 60086018. (DOI: 10.3390/molecules15096008).

24.O. A. Aiyegoro and A. I. Okoh, Preliminary phytochemical screening and in vitro antioxidant activities of the aqueous extract of Helichrysum longifolium DC, BMC Complementary and Alternative Medicine, 2010, 10(1), 21. (DOI: 10.1186/1472-6882-10-21).

25. W. S. Jung, I. M. Chung, S. H. Kim, M. Y. Kim MY, A. Ahmad and N. Praveen, In vitro antioxidant activity, total phenolics and flavonoids from celery (Apium graveolens) leaves, Journal of Medicinal Plants Research, 2011, 5(32), 7022-7030. (DOI: 10.5897/JMPR11.1129).

26. S. Chandra, P. Chatterjee, P. Dey, and S. Bhattacharya, Evaluation of in vitro antiinflammatory activity of coffee against the denaturation of protein, Asian Pacific Journal of Tropical Biomedicine, 2012, 2(1), 178-180. (DOI: 10.1016/S2221-1691(12)60154-3).

27. B. Kar, R. S. Kumar, I. Karmakar, N. Dola, A. Bala, U. K. Mazumder and P. K. Hadar, Antioxidant and in vitro anti-inflammatory activities of Mimusops elengi leaves, Asian Pacific Journal of Tropical Biomedicine, 2012, 2(2), S976-980. (DOI: 10.1016/S2221-1691(12)60346-3).

28. R. A. Mustafa, A. A. Hamid, S. Mohamed and F. A. Bakar, Total phenolic compounds, flavonoids, and radical scavenging activity of 21 selected tropical plants, Journal of Food Science, 2010, 75(1), 2835. (DOI: 10.1111/j.1750-3841.2009.01401.x).

29. M. Rana, J. Pant, A. Jantwal, A. J. Rana, J. Upadhyay and S. Bisht, In-vitro anti-inflammatory and antioxidant activity of ethanolic extract of Marchantia polymorpha in Kumaun region, World Journal of Pharmaceutical Research, 2017, 7(9), 864-875. (DOI: 10.20959/wjpr20189-12010).

30. V. Lobo, A. Patil, A. Phatak and N. Chandra, Free radicals, antioxidants and functional foods: Impact on human health, Pharmacognosy Reviews, 2010, 4(8), 118. (DOI: 10.4103/0973-7847.70902).

31.A. A. Basma, Z. Zakaria, L. Y. Latha and S. Sasidharan, Antioxidant activity and phytochemical screening of the methanol extracts of Euphorbia hirta L, Asian Pacific Journal of Tropical Medicine, 2011, 4(5), 386-390. (DOI: 10.1016/S1995-7645(11)60109-0). 
32.S. Asha, P. Thirunavukkarasu, V. M. Mani and A. M. Sadiq, Antioxidant activity of Euphorbia hirta Linn leaves extracts, European Journal of Medicinal Plants, 2016, 7, 1-4. (DOI:10.9734/ EJMP/2016/24952).

33.K. B. Pandey and S. I. Rizvi, Plant polyphenols as dietary antioxidants in human health and disease, Oxidative Medicine and Cellular Longevity, 2009, 2. (DOI:10.4161/oxim.2.5.9498).

34. Harasym J, Oledzki R. Effect of fruit and vegetable antioxidants on total antioxidant capacity of blood plasma, Nutrition, 2014, 30(5), 511-517. (DOI: 10.1016/j.nut.2013.08.019).

35. B. Yang, A. Kotani, K. Arai, and F. Kusu, Estimation of the antioxidant activities of flavonoids from their oxidation potentials, Analytical Sciences, 2001, 17(5), 599-604. (DOI: 10.2116/analsci.17.599)

36. R. Hirano, W. Sasamoto, A. Matsumoto, H. Itakura, O. Igarashi and K. Kondo, Antioxidant ability of various flavonoids against DPPH radicals and LDL oxidation, Journal of Nutritional Science and Vitaminology, 2001, 47(5), 357-362. (DOI: 10.3177/jnsv.47.357).

37.K. N. Prasad, B. Yang, X. Dong, G. Jiang, H. Zhang, H. Xie and Y. Jiang, Flavonoid contents and antioxidant activities from Cinnamomum species, Innovative Food Science \& Emerging Technologies, 2009, 10(4), 627-632. (DOI: 10.1016/j.ifset.2009.05.009).

38.Z. Gao, K. Huang, X. Yang and H. Xu , Free radical scavenging and antioxidant activities of flavonoids extracted from the radix of Scutellaria baicalensis Georgi, Biochimica et Biophysica Acta (BBA)-General Subjects, 1999, 1472(3), 643-650. (DOI: 10.1016/S0304-4165(99)00152-X).

39. M. Kratchanova, P. Denev, M. Ciz, A. Lojek and A. Mihailov, Evaluation of antioxidant activity of medicinal plants containing polyphenol compounds, comparison of two extraction systems, Acta Biochimica Polonica, 2010, 57(2). (DOI: 10.18388/abp.2010_2399).

40. T. Yoshida, K. Mori, T. Hatano, T. Okumura, I. Uehara, K. Komagoe and T. Okuda, Studies on inhibition mechanism of autoxidation by tannins and flavonoids, Radical-scavenging effects of tannins and related polyphenols on 1,1-diphenyl-2-picrylhydrazyl radical, Chemical and Pharmaceutical Bulletin, 1989, 37(7), 19191921. (DOI: 10.1248/cpb.37.1919).

41.I. M. C. Brighente, M. Dias, L. G. Verdi and M .G. Pizzolatti, Antioxidant activity and total phenolic content of some Brazilian species, Pharmaceutical Biology, 2007, 45(2), 156-161. (DOI: 10.1080/13880200601113131).

42. M. Okawa, J. Kinjo, T. Nohara and M. Ono, DPPH (1,1-diphenyl-2-picrylhydrazyl) radical scavenging activity of flavonoids obtained from some medicinal plants, Biological and Pharmaceutical Bulletin, 2001, 24(10), 12021205. (DOI: 10.1248/bpb.24.1202).

43.D. K. Badyal and C. Desai, Animal use in pharmacology education and research: The changing scenario, Indian Journal of Pharmacology, 2014, 46(3), 257.(DOI: 10.4103/0253-7613.132153).

44. L. Saso, G. Valentini, M. L. Casini, E. Grippa, M. T. Gatto, M. G. Leone and B. Silvestrini, Inhibition of heat-induced denaturation of albumin by nonsteroidal anti-inflammatory drugs (NSAIDs): Pharmacological implications, Archives of Pharmacal Research, 2001, 24(2), 150-158. (DOI: 10.1007/BF02976483).

45. M. Govindappa, N. Bharath, H. B. Shruthi, T. S. Sadananda and P. Sharanappa, Antimicrobial, antioxidant and in vitro anti-inflammatory activity and phytochemical screening of Crotalaria pallida Aiton, African Journal of Pharmacy and Pharmacology, 2011, 5(21), 2359-2371. (DOI: 10.5897/AJPP11.038).

46. A. Russo, R. Acquaviva, A. Campisi, V. Sorrenti, C. Di Giacomo, G. Virgata, M. L. Barcellona and A. Vanella, Bioflavonoids as antiradical, antioxidants and DNA cleavage protectors, Cell Biology and Toxicology, 2000, 16(2), 91. (DOI: 10.1023/A:1007685909018).

47. J. A. Knight, Free radicals: their history and current status in aging and disease, Annals of Clinical \& Laboratory Science, 1998, 28(6), 331-346.

48. M. Atanassova, S. Georgieva and K. Ivancheva, Total phenolic and total flavonoid contents, antioxidant capacity and biological contaminants in medicinal herbs, Journal of the University of Chemical Technology \& Metallurgy, 2011, 46(1).

49. E. A. Lissi, B. Modak, R. Torres, J. Escobar and A. Urzua, Total antioxidant potential of resinous exudates from Heliotropium species, and a comparison of the ABTS and DPPH methods, Free Radical Research, 1999, 30(6), 471-477. (DOI: 10.1080/10715769900300511).

50 M. Z. Salem, H. M. Ali, N. A. El-Shanhorey and A. Abdel-Megeed, Evaluation of extracts and 
essential oil from Callistemon viminalis leaves: Antibacterial and antioxidant activities, total phenolic and flavonoid contents, Asian Pacific Journal of Tropical Medicine, 2013, 6(10), 785791. (DOI: 10.1016/S1995-7645(13)60139-X).

51.A. A. Adedapo, F. O. Jimoh, A. J. Afolayan and P. J. Masika, Antioxidant activities and phenolic contents of the methanol extracts of the stems of Acokanthera oppositifolia and Adenia gummifera, BMC Complementary and Alternative Medicine, 2008, 8(1), 54. (DOI: 10.1186/14726882-8-54).(DOi: 10.1186/1472-6882-8-54).

52.T. Umaru, C. O. Nwamba, I. Kolo and U. U. Nwodo, Antimicrobial activity of non-steroidal anti-inflammatory drugs with respect to immunological response: Diclofenac sodium as a case study, African Journal of Biotechnology, 2009, 8(25).

53. G. Dhalendra, T. Satapathy and A. Roy, Animal models for inflammation: A review, Asian Journal of Pharmaceutical Research, 2013, 3(4), 207-212.

54.F.Alhakmani, S. Kumar and S.A. Khan, Estimation of total phenolic content, in-vitro antioxidant and anti-inflammatory activity of flowers of Moringa oleifera, Asian Pacific Journal of Tropical Biomedicine, 2013, 3(8), 623. (DOI: 10.1016/ S2221-1691(13)60126-4).

55.A. E. Mirsky and L. Pauling, On the structure of native, denatured, and coagulated proteins, Proceedings of the National Academy of Sciences of the United States of America, 1936, 22(7), 439. (DOI: 10.1073/pnas.22.7.439).
56. A. R. Chopade, P. M. Somade and F. J. Sayyad, Membrane stabilizing activity and protein denaturation: A possible mechanism of action for the anti-inflammatory activity of Phyllanthus amarus, Journal of Krishna Institute of Medical Sciences University, 2012, 1, 67-72.

57. A. S. Ravipati, L. Zhang, S. R. Koyyalamudi, S. C. Jeong, N. Reddy, J. Bartlett, P. T. Smith, K. Shanmugam, G. Münch, M. J. Wu and M. Satyanarayanan, Antioxidant and antiinflammatory activities of selected Chinese medicinal plants and their relation with antioxidant content, BMC Complementary and Alternative Medicine, 2012, 12(1), 173. (DOI: 10.1186/14726882-12-173).

58. P. Rathee, H. Chaudhary, S. Rathee, D. Rathee, V. Kumar and K. Kohli, Mechanism of action of flavonoids as anti-inflammatory agents: a review, Inflammation \& Allergy-Drug Targets (Formerly Current Drug Targets-Inflammation \& Allergy), 2009, 8(3), 229-235. (DOI: 10.2174/187152809788681029).

59. R. Risitano, M. Currò, S. Cirmi, N. Ferlazzo, P. Campiglia, D. Caccamo, R. Ientile and M. Navarra, Flavonoid fraction of Bergamot juice reduces LPSinduced inflammatory response through SIRT1mediated NF- $\kappa$ B inhibition in THP-1 monocytes, PLoS One, 2014, 9(9), e107431.(DOI: 10.1371/ journal.pone.0107431). 